\title{
RISK FACTORS FOR B4C COMPOSITE UTILIZATION IN TRIBOLOGICAL PROCESSES
}

\author{
${ }^{1}$ Hadi HUSAIN, ${ }^{2}$ Zdeněk HAZDRA, ${ }^{3} J a n$ KUDLÁČEK, ${ }^{4}$ Jiří KUCHAŘ \\ ${ }^{1}$ Czech Technical University in Prague, Prague, Czech Republic, EU, hadi.husain@fs.cvut.cz
}

https://doi.org/10.37904/metal.2021.4186

\begin{abstract}
Tribology deals with the interaction of surfaces in relative motion depending on their design, friction, wear and lubrication. Proper use of PTA coatings can significantly reduce friction and wear, leading to reduced energy consumption and extended service life.

According to various experiences and areas of application, tribological coatings play a key role in the performance of mechanical components and products by increasing the life of the working material and reducing energy dissipation as heat, thus increasing the efficiency of the moving.

Article deals with tribology wear, abrasion, resistance of plasma deposited cermet's based on $\mathrm{B}_{4} \mathrm{C}$ particles in $\mathrm{Ni}$-based matrix, impact of the phenomenon on industrial tribology and related processes on the environment.

The main part of this case study is the risk factor estimation of plasma-welded material on tribologically treated surfaces by two main factors.

First, showing the impact of heat-treated Inconel $+\mathrm{B}_{4} \mathrm{C}$ samples during tribology test on surface roughness and friction coefficient. Second showing the impact of possible impurities generated during this process on the environment.
\end{abstract}

Keywords: Risk, tribology, friction, plasma-transferred arc, surface coating

\section{INTRODUCTION}

Ni-based super alloy type Incone ${ }^{\circledR}$ is a solid solution derived from refractory elements including niobium and molybdenum, in a nickel-chromium matrix [1]. Alloy of the type 625 has good corrosion resistance, good combination of yield, tensile, high temperature strength, excellent weld ability and creep strength [2], that led to its application in different areas such as aeronautics, aerospace, marine, nuclear, chemical and petrochemical industries. [3] Talking about wear resistance like valve components, for example, is considered as potential application due to robustness necessity [4]. Depending on previous researches Incone $\left.\right|^{\circledR}$ usage and applications in manufacturing technologies is remarkably difficult and expensive, due to fact that it has low wear resistance characteristics. [5]

Boron carbide is characterized by a unique combination of properties that make it a choice for a wide range of engineering applications [6]. Boron carbide is used in refractory applications, due to its high melting point and thermal stability [7]. It is used as abrasive powders and coatings due to its extreme abrasion resistance; it excels in ballistic performance due to its high hardness and low density; In addition, boron carbide is a high temperature semiconductor that can potentially be used for novel electronic applications [5].

Plasma powder transferred arc welding (PPTAW) is one of the techniques used in modification and regeneration of the surfaces of machine components. By correctly adjusting the arc power, this method allows control of the substrate penetration depth with high accuracy, achieving less than $5 \%$ base metal content in the deposit [1]. Thus, in order to obtain a coating with specific operating characteristics, it is sufficient to create a coating of small thickness, which has a measurable economic effect. In addition, selecting appropriate 
plasma welding parameters allows surface layers obtain with thicknesses from 0.25 to $5-7 \mathrm{~mm}$ and a high level of metallurgical purity [8] (Figure 1).

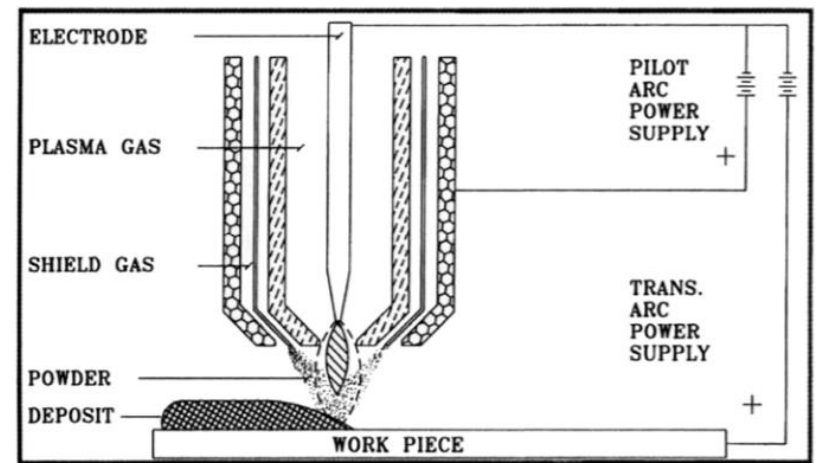

Figure 1 Schematic representation of the PPTAW deposited process [9]

A cermet is a composite material composed of ceramic (cer) and metal (met) materials. A cermet in this study is designed to have the optimal properties of both a Boron Carbides $\left(\mathrm{B}_{4} \mathrm{C}\right)$ ceramic, such as high temperature resistance and hardness, and those of an Incone ${ }^{\circledR}$ alloy, such as ability to undergo plastic deformation. [10], [11]. Following to properties of Inconel matrix and $\mathrm{B}_{4} \mathrm{C}$ particles, the cermet was chosen.

Frictional wear is the mechanical and/or chemical damage, caused by friction, which affects the quality of the materials in contact with each other [12]. Therefore, continuous improvement in the performance in terms of shape stability, impact resistance is required [8], [10]. Friction and wear (typically wear rates and wear resistance) material properties are measured Estimated to determine using various types of tests, while ball on flat disk test being probably one of the most common [13]. The popularity of the method is due to its relative simplicity and abundance of the tribological contacts that can be well described by the simple pin on disk motion [14].

The specific field of green or environment-friendly tribology emphasizes the aspects of interacting surfaces in relative motion, which is important for energy or environmental. The control of friction and wear, which is of importance for energy conservation and conversion, environmental aspects of lubrication and surfacemodification techniques and tribological aspects of green applications, such as wind-power turbines, tidal turbines or solar panels. [15]

Previous studies selected a single tribo-pair, and just paid close attention to the tribo-chemical reactions of $\mathrm{B}_{4} \mathrm{C}$, but lost sight of having cermet's based on $\mathrm{B}_{4} \mathrm{C}$ particles in Ni-based matrix [16], [6].

Hence, it is necessary to investigate the effect of the mating material on the tribological performances of the cermet's based on $\mathrm{B}_{4} \mathrm{C}$ particles in Ni-based matrix.

This article estimates risk of damaged and occurred wear to Cermet $\left(\mathrm{B}_{4} \mathrm{C}\right.$ Ceramics with Inc.625, applied by plasma welding on surfaces), by tribological in-vitro test.

\section{EXPERMENTAL}

\subsection{Inconel 625 samples preparation}

Samples were deposited by a manually controlled procedure, with a commercially available plasma hard facing automate PPC 250 R6 (KSK, s.r.o., Czech Republic) in a tight chamber. Used machine is designated for glass industry applications, mainly for hard facing of glass mold edges. The hard facing automate can work with plasma current pulses up to $200[\mathrm{~Hz}]$ between 50 and 250 [A]. [9] 


\subsection{PPAD processing parameters:}

The coatings consist of one layer. This layer was done by using pulsation between 45 and 125 [A] with a frequency of $5[\mathrm{~Hz}]$ to ensure the good metallurgical bond between the substrate and deposited layer.

Parameters for study experiment have been chosen (Table 1).

Table 1 Processing parameters of pulsed plasma arc deposition

\begin{tabular}{|c|c|c|c|c|c|c|}
\hline Parameters & $\begin{array}{c}\text { Peak } \\
\text { current IP } \\
\text { (A) }\end{array}$ & $\begin{array}{c}\text { Background } \\
\text { current Ib } \\
\text { (A) }\end{array}$ & $\begin{array}{c}\text { Pulse } \\
\text { frequency f } \\
\text { (Hz) }\end{array}$ & $\begin{array}{c}\text { Welding } \\
\text { speed } \\
(\mathbf{m} / \mathbf{m i n})\end{array}$ & $\begin{array}{c}\text { Powder Filler } \\
\text { material } \\
(\mathbf{g} / \mathbf{m i n})\end{array}$ & Oscillation \\
\hline Value & 100 & 45 & 28.7 & 0.4 & 1.5 & $28 \mathrm{~mm}$ by $28 \mathrm{~mm} / \mathrm{s}$ \\
\hline
\end{tabular}

\subsection{Temperature Measurement during samples Preparation}

Temperature was measured by thermocouples T1, T2, and T3. These measuring points were attached to samples according to (Figure 2). Surfacing procedure took from 2 to $6 \mathrm{~min}$. During this surfacing time, the temperature of the work piece increased rapidly to reach maximum limit approx. $900{ }^{\circ} \mathrm{C}$ on $\mathrm{T} 1$ point. [8]

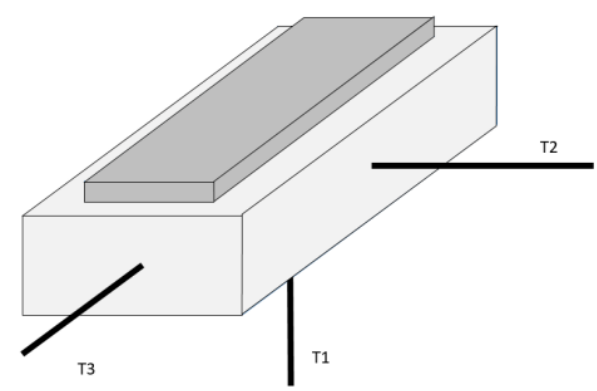

Figure 2 Attached Temperature Measuring Points on testing samples

\subsection{Testing samples heat treatment before Tribology test}

Heat Treatment is necessary for the precipitation of strengthening phases and improvement of the mechanical properties. Detailed conditions of applied heat treatment method are listed in Table 2. [1], [2], [8]

Table 2 Heat Treatment Plan

\begin{tabular}{|l|l|}
\hline Step 1 aging & Heat to $720^{\circ} \mathrm{C}$ during $180 \mathrm{~min}$, hold for $8 \mathrm{~h}$, furnace cool to $620^{\circ} \mathrm{C}$, hold for $8 \mathrm{~h}$, air cool \\
\hline Step 2 solution & Heat to $980^{\circ} \mathrm{C}$ during $180 \mathrm{~min}$, hold for $1 \mathrm{~h}$, air cool \\
\hline
\end{tabular}

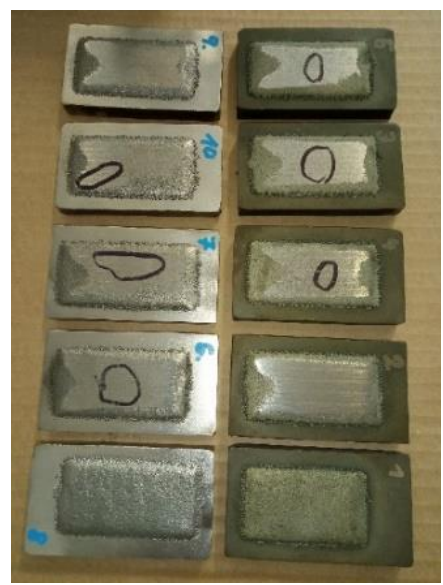

Figure 3 Parts polished and prepared for tribology test 
Due to fact that samples surface is rough and would make a high deformation during tribology test. Grinding for samples' surface was done to make surface suitable for testing applications. (Figure 3)

\subsection{Tribology Test}

\subsubsection{Roughness Measurement}

Two roughness parameters namely average roughness $(\mathrm{Ra})$ and mean peak to valley height $(\mathrm{Rz})$, which are used to determine quantities surface characteristics of the panels, were measured. Showing three measuring points on the same horizontal line. Each one of these measuring points has $1 \mathrm{~cm}$ length.

\subsubsection{Ball on flat disk Tribology Test}

Tribological test parameters are: Measured distance $30(\mathrm{~mm})$, Velocity: $1(\mathrm{~mm} / \mathrm{s})$, Acceleration: 0.1 (s), Duration: $30(\mathrm{~min})$, Force $10(\mathrm{~N})$. By running this test, we have concluded friction coefficient results.

\section{RESULT AND DISCUSSION}

SAMPLES: Ten deposits of cermets with $10 \mathrm{~mm}$ thickness have been prepared. Particles (Ni $62570 \%+\mathrm{B}_{4} \mathrm{C}$ $30 \%$ ) were deposited as one layer (Figure 4).

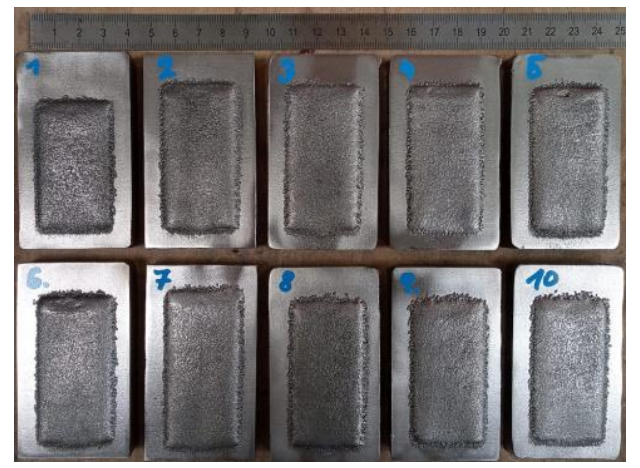

Figure 410 samples with one layer deposited cermets

of samples during PTA: Welding process was continuous and no fast decreasing temperature of the work piece was obtained. Figure 5 shows temperature change was the biggest for the deposits welded with welding parameters $\mathrm{T} 1$, because of high heating temperature, up to $900^{\circ} \mathrm{C}$ and was controlled below $1000^{\circ} \mathrm{C}$.

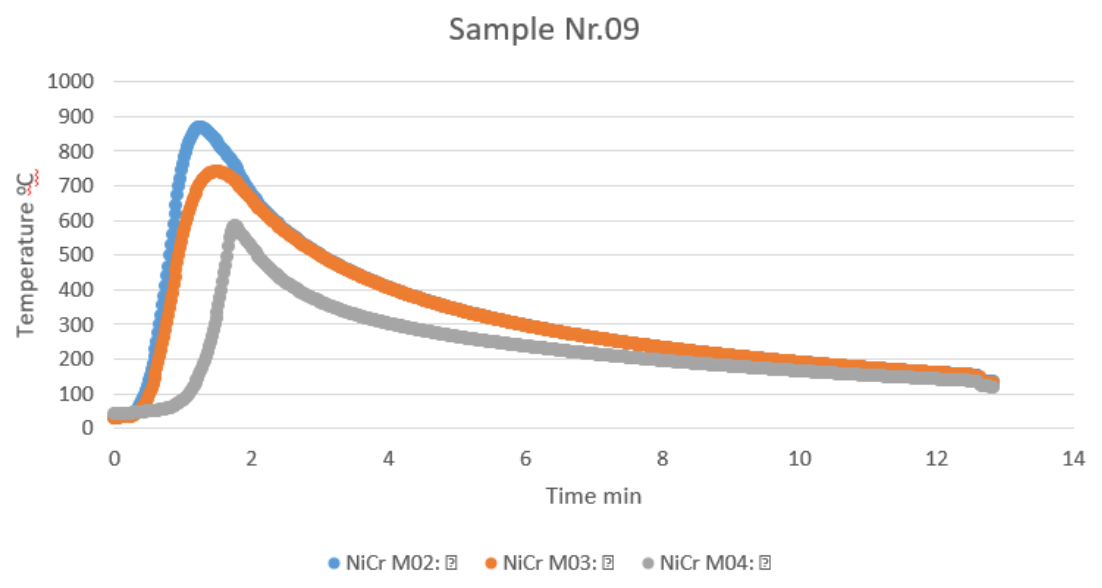

Figure 5 Temperature profile during PTA surfacing 
Tribology test: Two results were obtained during the test and they will be considered as a part of our risk assessment:

- Result of surface roughness of the parts before and after heat treatment are the same. No remarkable differences according.

- The friction coefficient, of Inconel with $\mathrm{B}_{4} \mathrm{C}$ composite welded by PTA deposits without heat treatment, was (0.166) lower when compared to the heat-treated samples (0.30675).

Table 3 Average roughness values comparing with/ without heat treatment spacing)

\begin{tabular}{|c|c|c|c|c|c|c|c|c|}
\hline \multicolumn{3}{|c|}{ Measuring Points } & \multicolumn{2}{|c|}{1} & \multicolumn{2}{|c|}{2} & \multicolumn{2}{|c|}{3} \\
\hline Axis & $\begin{array}{c}\text { Surface } \\
\text { Polishing }\end{array}$ & $\mathrm{HT}$ & $\mathrm{Ra} \mu \mathrm{m}$ & $\mathrm{Rz} \mu \mathrm{m}$ & $\mathrm{Ra} \mu \mathrm{m}$ & $\mathrm{Rz} \mu \mathrm{m}$ & $\mathrm{Ra} \mu \mathrm{m}$ & $\mathrm{Rz} \mu \mathrm{m}$ \\
\hline$X$ & Yes & Yes & 1.4275 & 11.78 & 1.595 & 13.06 & 1.8575 & 14.76 \\
\hline $\mathrm{Y}$ & Yes & Yes & 2.025 & 14.6575 & 2.2325 & 14.2 & 2.415 & 15.9675 \\
\hline$x$ & Yes & No & 1.0475 & 10.6775 & 1.05 & 9.65 & 1.745 & 15.1825 \\
\hline $\mathrm{Y}$ & Yes & No & 1.9525 & 14.385 & 2.17 & 17.8575 & 2.32 & 16.3675 \\
\hline
\end{tabular}

\section{CONCLUSION}

A relative risk assessment considered here for the industrial fabrication and application of these cermets. The production processes for these materials were selected for this analysis, based on their current or near-term potential for large-scale production and commercialization.

As conclusion, a risk Estimation, based on mechanical proof, clarify that by applying heat treatment for studied samples, a wear resistance improvement was noticed and proved.

\section{ACKNOWLEDGEMENTS}

The research was financed by SGS19/163/OHK2/3T/12. Research, optimization and innovation of production processes. Thanks to Pavel Rohan for providing samples of cermet coatings and thanks to Mikronex for grinding the surfaces of the samples.

\section{REFERENCES}

[1] XU, F.J., LV, Y.H., XU, B.S., LIU, Y.X., SHU, F.Y., HE, P. Effect of deposition strategy on the microstructure and mechanical properties of Inconel 625 superalloy fabricated by pulsed plasma arc deposition. Materials \& Design. [online]. 2013, vol. 45, pp. 446-445. Available from: https://doi.org/10.1016/j.matdes.2012.07.013.

[2] SHANKAR, V., RAO, K.B.S., MANNAN, S.L. Microstructure and mechanical properties of inconel 625 superalloy. Journal of Nuclear Materials. [online]. 2001, vol. 288, pp. 222-232. Available from: https://doi.org/10.1016/S00223115(00)00723-6.

[3] FLOREEN, S., FUCHS, G.E., YANG, W.J. Metallurgy of alloy 625. In: Superalloys 718, 625 and Various Derivatives. Pittsburgh, PA, U.S.A.: The Minerals, Metals and Materials Society, 1994, pp. 13-37.

[4] XU, F., LV, Y., LIU, Y., XU, B., HE, P. Effect of Heat Treatment on Microstructure and Mechanical Properties of Inconel 625 Alloy Fabricated by Pulsed Plasma Arc Deposition. Physics Procedia. [online]. 2013, vol. 50, pp. 4853. Available from: https://doi.org/10.1016/j.phpro.2013.11.010.

[5] GUNEN, A., KANCA, E. Microstructure and Mechanical Properties of Borided Inconel 625 Superalloy. Matéria. [online]. 2017, vol. 22, no 2. Available from: https://doi.org/10.1590/S1517-707620170002.0161.

[6] XUEQIAN, CAO, LUNLIN, SHANG, YONGMIN, LIANG, ZHIBIN, LU, GUANGAN, ZHANG, QUNJI, XUE. Tribological investigation of boron carbide films sliding against different mating materials under high relative humidity. Ceramics-Silikáty. 2019, vol. 63, no. 4, pp. 380-389. 
[7] DOMNICH, V., REYNAUD, S., HABER, R.A., CHHOWALLA, M. Boron Carbide: Structure, Properties, and Stability under Stress. Journal of the American Ceramic Society. 2011, vol. 94, no. 11, pp. 3605-3628. Available from: https://doi.org/10.1111/j.1551-2916.2011.04865.x.

[8] XU, F., LV, Y., LIU, Y., SHU, F., HE, P., XU, B. Microstructural Evolution and Mechanical Properties of Inconel 625 Alloy during Pulsed Plasma Arc Deposition Process. Journal of Materials Science \& Technology. 2013, vol. 29, no 5, pp. 480-488. Available from: https://doi.org/10.1016/i.jmst.2013.02.010.

[9] KERÄNEN, M. Effect of Welding Parameters of Plasma Transferred Arc Welding Method on Abrasive Wear Resistance of 12V Tool Steel Deposit. Espoo, 2010. Doctoral Dissertation. Aalto University.

[10] WANG, M., WANG, W.X., CHEN, H.S. et al. Understanding micro-diffusion bonding from the fabrication of B4C/Ni composites. International Journal of Minerals, Metallurgy, and Materials. 2018, vol. 25, pp. 365-374. Available from: https://doi.org/10.1007/s12613-018-1580-0.

[11] BOBER, M. Composite coatings deposited by plasma transfer - characteristics and formation. Welding International. 2015, vol. 29, no 12, pp. 946-950. Available from: https://doi.org/10.1080/09507116.2014.937607.

[12] FENGAB, K., CHENAB, Y., DENGAB, P., LI, Y., ZHAO, H., LU, F., LI, R., HUANG, J., LI, Z. Improved hightemperature hardness and wear resistance of Inconel 625 coatings fabricated by laser cladding. Journal of Materials Processing Technology. 2017, vol. 243, pp. 82-91. Available from: https://doi.org/10.1016/j.jmatprotec.2016.12.001.

[13] KUWAHARA, T., ROMERO, P.A., MAKOWSKI, S., WEIHNACHT, V., MORAS, G., MOSELER, M. Mechanochemical decomposition of organic friction modifiers with multiple reactive centres induces superlubricity of ta-C. Nature Communications. 2019, vol. 10, no. 151. Available from: https://doi.org/10.1038/s41467-018-08042-8.

[14] Element Materials Technology. Pin on Disk Wear Testing. [online]. [cited 2021-03-16]. Available from: https://www.element.com/more-sectors/medical-device/pin-on-disk-wear-testing.

[15] BHATT, I., TRIPATHI, B.N. Interaction of engineered nanoparticles with various components of the environment and possible strategies for their risk assessment. Chemosphere. 2011, vol. 82, no 3, pp. 308-317. Available from: https://doi.org/10.1016/j.chemosphere.2010.10.011.

[16] CAO, X., SHANG, L., LIANG, Y., LU, Z., ZHANG, G., XUE, Q. The effect of tribo-chemical reactions of mating materials on tribological behaviors of the B4C film in various relative humidity environments. Ceramics International. 2019, vol. 45, no 4, pp. 4581-4589. Available from: https://doi.org/10.1016/j.ceramint.2018.11.145. 